Article

\title{
Combination of Mycorrhizal Symbiosis and Root Grafting Effectively Controls Nematode in Replanted Coffee Soil
}

\author{
The Trinh Pham ${ }^{1}$, Bach Long Giang ${ }^{2}$, Ngoc Hoi Nguyen ${ }^{3}$, Pham Nguyen Dong Yen ${ }^{3}$, \\ Vo Do Minh Hoang ${ }^{3}$, Bui Thi Lien $\mathrm{Ha}^{3}$ and Ngoc Thuy Trang Le ${ }^{4, *(D)}$ \\ 1 Department of Science and Technology in DakLak province, 15A Truong Chinh, Buon Ma Thuot City 630000, \\ Vietnam; trinhkhcn@yahoo.com \\ 2 Faculty of Chemical Engineering and Food Technology, Nguyen Tat Thanh University, 300A Nguyen Tat \\ Thanh, District 4, Ho Chi Minh City 700000, Vietnam; blgiang@ntt.edu.vn \\ 3 Institute of Applied Materials Science, Vietnam Academy of Science and Technology, \\ Ho Chi Minh City 700000, Vietnam; hoi83bmt@gmail.com (N.H.N.); \\ phamngdongyen@gmail.com (P.N.D.Y.); hvodominh@gmail.com (V.D.M.H.); lienha09@gmail.com (B.T.L.H.) \\ 4 Institute of Research and Development, Duy Tan University, Danang 550000, Vietnam \\ * Correspondence: lenthuytrang4@duytan.edu.vn
}

Received: 20 March 2020; Accepted: 25 April 2020; Published: 27 April 2020

\begin{abstract}
Replanting for sustainable development is one of the critical missions of the coffee industry in the Daklak province, Vietnam. However, this plan has been faced with many difficulties including poor survival and growth rates due to the low nematode tolerance of young coffee plants in replanted fields. Mycorrhizal symbiosis and grafting have been applied separately but not yet resulted in the expected results of the replanting plan. Whether the combination of them would help managing nematode in the soil and consequently enhance the replanted efficiency is largely unknown. Mycorrhizal symbiosis was applied to Coffea canephora plants or/and grafted onto Coffea liberica rootstock, which were grown and compared to the untreated ones in both net-house-pots and the replanted plantation. The survival rate, growth indicators and the soil pathogens were monitored during the experimental periods. The combination of grafting and mycorrhiza symbiotic techniques significantly decreased the nematode densities in the replanted soil. As a result, the survival rate and growth indicators of the coffee in the replanted soil treated by the combined technique were better than treated by the two separate techniques. The results suggested that the combination of grafting and mycorrhiza symbiotic techniques would propose a potentially effective Pratylenchus coffeae and Meloidogyne incognita nematode management in replanted coffee fields in the Daklak province, Vietnam.
\end{abstract}

Keywords: coffee; grafting; mycorrhizal symbiosis; nematode management; replanted coffee soil

\section{Introduction}

Vietnam is the second largest coffee producer and the biggest Robusta exporter in the world. Recently, Vietnam's coffee area was about 720 thousand ha with the production of more than 1700 thousand tons, of which the Daklak province is the biggest coffee region with 204 thousand ha and 490 thousand tons [1]. Due to the sustainable development of the coffee industry, "Coffee Rejuvenation Strategies in Vietnam" were decided by the government which planned for nearly 28 thousand ha of old, low production and low quality coffee areas to be renewed [2-4]. However, the replanted area of coffee in the province has reached a modest figure compared to the plan expectation due to the low survival rate of young coffee trees in replanted fields [5]. 
Plant-parasitic nematodes, a major limiting factor in crop production areas worldwide, were reported to cause great economic losses to both the coffee farmers and the industry [6]. Scientists have been looking for a variety of tools and methods to control plant-parasitic nematodes that are not only highly effective but also ecofriendly [7-10]. In Vietnam, due to the long-term monoculture and intensive cultivation of coffee with mainly chemical fertilizers and almost no organic fertilizers, harmful microorganisms are more likely to survive and thrive than beneficial microorganisms. Twenty-one plant-parasitic nematodes species representing 14 genera were recovered from coffee cultivating soil, in which Pratylenchus coffeae and Meloidogyne spp. were reported to be the predominant genera, which were widely distributed in coffee plantations with 124 and 257 individuals $/ 250 \mathrm{~cm}^{3}$, respectively [11]. Nematodes in replanted soils are considered as one of the reasons for the poor result of the Daklak Province Coffee Replanted Plan even though several approaches have been studied and applied to control nematodes in replanted coffee farms such as plowing land after up-rooting and combining with rotation with soil treatments [12].

Mycorrhizal symbiosis and grafting are two separately common horticultural techniques which have been studied and applied in the cultures of many crops [13,14]. Mycorrhiza stimulates coffee tree growth from the nursery stage until the harvesting stage and largely determines the bean yield and quality. Even when soil fertility was reduced and coffee farms were degraded, active infection of mycorrhiza could restore coffee growth. It is also proven that mycorrhiza helps coffee plants to stabilize and prevent nematode attacks [15-17]. On the other hand, grafting is a practice where a rootstock is desired which has better characteristics than the commercial variety [18]. Among the recommended rootstocks for coffee, the most common are the Robusta Nemaya variety and the Arabica scion on the Robusta nematode-resistant rootstock, which have been successfully employed in Central America [19,20]. However, the poor compatibility of Robusta grafted onto Excelsa (Syn. liberica) rootstocks, which resisted nematodes, was reported from Indonesia [21]. Clear evidence of graft union problems of Robusta grafted onto Excelsa rootstocks was also seen in a field visit in Vietnam. Some coffee farmers have used Excelsa coffee seedlings for rootstocks, but up to $60 \%$ losses still occurred due to nematodes since this species was genetically very diverse and seedlings segregated widely for any resistance [22]. Whether the combination of mycorrhizal symbiosis and grafting would help controlling nematodes in the soil and consequently enhance the replanted efficiency is largely unknown.

In this study, it was hypothesized that the combination of grafting and mycorrhizal symbiosis could increase the survival rate and growth of young Robusta coffee trees through controlling nematode densities in the soil. Experiments were carried out with original plants of $C$. canephora as the controls and treated plants to which were applied mycorrhizal symbiosis or/and grafted onto C. liberica rootstock in net-house-pots and the replanted plantation. The survival rate, growth indicators and the nematode densities from the controls and the treated plants were monitored and compared during the experimental periods. From these results, appropriate cropping practices could be figured out to control nematodes in replanted coffee fields in the Daklak province, Vietnam.

\section{Results}

\subsection{Nematode Densities in Soil in Net-House-Pot Experiments}

To evaluate the effect of the combination of mycorrhical symbiosis and grafting on nematode management, C. canephora (commonly known as Robusta coffee) plants with mycorrhizal symbiosis or/and grafted onto C. liberica rootstock were first grown and compared to the untreated ones after two years of cultivation in net-house-pots. Moreover, the previous coffee surveys in the DakLak province, Vietnam, have revealed a widespread incidence of five nematode genera in Robusta coffee roots, with Pratylenchus coffeae (P. coffeae) and Meloidogyne incognita (M. incognita) being considered the most important [22]. Therefore, to ascertain the effect of mycorrhiza symbiosis combined with grafting on nematode management, the densities of the two nematodes in the soil after two years testing were determined and are shown in Figure 1. 


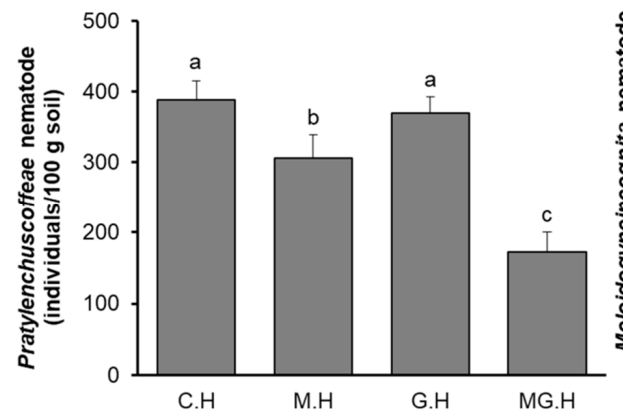

(a)

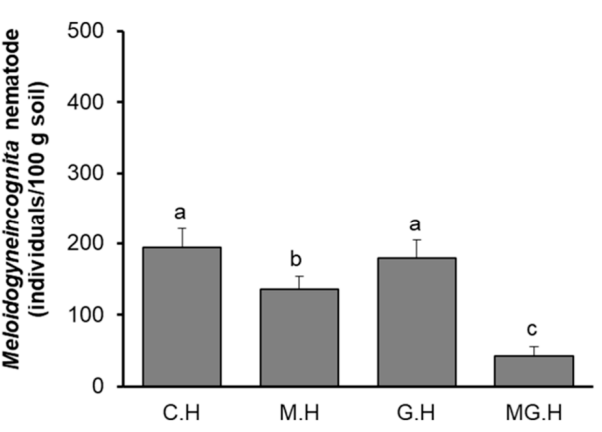

(b)

Figure 1. Densities of nematodes after 2 years of cultivating soils in net-house-pot experiments. (a) P. coffeae density (individuals/100 g soil); (b) M. incognita density (individuals $/ 100 \mathrm{~g}$ soil). C.H, control; M.H, mycorrhizal symbiosis treatment; G.H, grafting treatment; MG.H, combined mycorrhizal symbiosis and grafting treatment. Bars show means \pm SD. Bars with the same letters are not statistically different based on the least significant difference at $p<0.05$.

As shown in Figure 1, the densities of both P. coffeae and M. incognita of the control (C.H), which was original C. canephora without mycorrhizal symbiosis or grafting treatments, were higher than the others treated with mycorrhizal fungi or/and grafting. Independently, the mycorrhizal symbiosis showed better effects on reducing the nematode densities compared to grafting. Soil from the mycorrhizal symbiosis treatment (M.H) had both P. coffeae and M. incognita densities lower than in the grafted treatment (G.H). No statistically significant differences of nematode densities were recorded between the soil samples from C.H and G.H treatments. Interestingly, the soil from the samples treated with mycorrhizal symbiosis combined with grafting (MG.H) had significant lower nematode densities with 173 individuals/100 g soil for P. coffeae (Figure 1a) and 43 individuals/100 g soil for M. incognita (Figure 1b) $(p<0.05)$.

\subsection{Survival Rate and Growth Indicators of Young Robusta Trees in Net-House-Pot Experiments}

The brief results of the survival rate and growth indicators of the young Robusta trees in the net-house-pots are presented in Table 1. After two years of cultivation in net-house-pots, the survival rates and especially the growth indicators of all the treatments were higher than the control. Mycorrhizal symbiosis and grafting techniques separately slightly increased the growth indicators of the treated young Robusta, however, the differences were not statistically significant at $p<0.05$. In addition, the young Robusta trees strongly improved their survival rate and growth indicators when they were treated with the combination of the mycorrhizal symbiosis and the grafting. This result was according to the nematode density results explained before.

Table 1. Survival rate and the growth indicators of the young Robusta trees after 2 years of cultivation in net-house-pots.

\begin{tabular}{cccccc}
\hline & & \multicolumn{4}{c}{ Growth Indicators } \\
\cline { 3 - 6 } Treatment & Survival Rate (\%) & $\begin{array}{c}\text { Tree Height } \\
\mathbf{( c m )}\end{array}$ & $\begin{array}{c}\text { Stump } \\
\text { Diameter (cm) }\end{array}$ & $\begin{array}{c}\text { Canopy } \\
\text { Diameter (cm) }\end{array}$ & $\begin{array}{c}\text { No. of 1st } \\
\text { Branch Pairs }\end{array}$ \\
\hline C.H & $66.7^{\mathrm{a}}$ & $130.2^{\mathrm{a}}$ & $2.37^{\mathrm{a}}$ & $135.0^{\mathrm{a}}$ & $8.75^{\mathrm{a}}$ \\
M.H & $78.2^{\mathrm{b}}$ & $138.3^{\mathrm{a}}$ & $2.40^{\mathrm{a}}$ & $138.0^{\mathrm{a}}$ & $9.82^{\mathrm{a}}$ \\
G.H & $72.3^{\mathrm{b}}$ & $138.2^{\mathrm{a}}$ & $2.54^{\mathrm{a}}$ & $133.5^{\mathrm{a}}$ & $9.43^{\mathrm{a}}$ \\
MG.H & $100^{\mathrm{c}}$ & $147.4^{\mathrm{b}}$ & $2.73^{\mathrm{b}}$ & $145.9^{\mathrm{b}}$ & $10.63^{\mathrm{b}}$ \\
CV (\%) & $2.69^{\mathrm{b}}$ & $4.16^{\mathrm{b}}$ & 3.41 & 4.25 & 4.26 \\
LSD $_{0.05}$ & 3.523 & 4.274 & 0.458 & 6.58 & 2.366 \\
\hline
\end{tabular}

C.H, control; M.H, mycorrhizal symbiosis treatment; G.H, grafting treatment; MG.H, combined mycorrhizal symbiosis and grafting treatment. CV, Coefficient of variation. LSD, Least significant difference. Means with the same letters are not statistically different based on the least significant difference at $p<0.05$. 


\subsection{Nematode Densities in Soil in Replanted Field Experiments}

To confirm the efficiency of the combined technique, the same treatments included the control (C.F), which was original C. canephora with neither mycorrhizal symbiosis nor grafting treatments, C. canephora trees with applied mycorrhizal symbiosis (M.F), C. canephora trees grafted onto C. liberica rootstock (G.F) and C. canephora trees treated with the combined technique (MG.F) which were grown and compared after two years of cultivation on replanted coffee fields. The densities of P. coffeae and M. incognita in the soil after two years testing were determined and are shown in Figure 2.

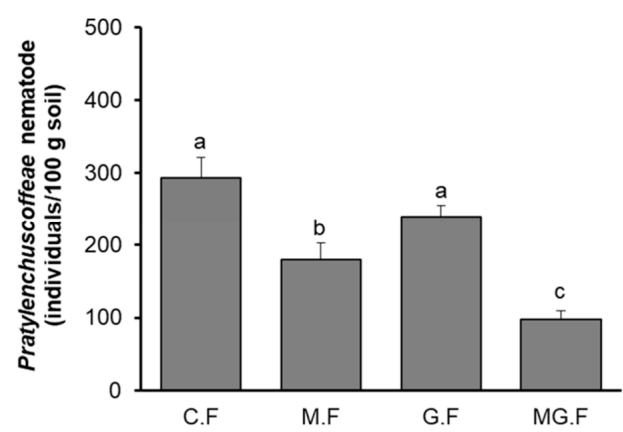

(a)

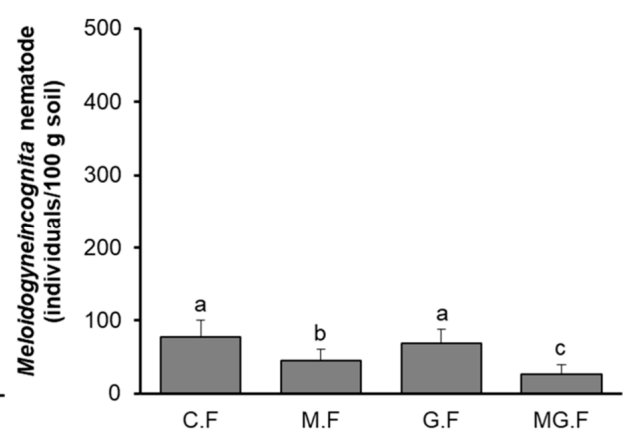

(b)

Figure 2. Densities of nematodes after 2 years of cultivating soils in replanted field experiments. (a) P. coffeae density (individuals/100 g soil); (b) M. incognita density (individuals/100 g soil). C.F, control; M.F, mycorrhizal symbiosis treatment; G.F, grafting treatment; MG.F, combined mycorrhizal symbiosis and grafting treatment. Bars show means \pm SD. Bars with the same letters are not statistically different based on the least significant difference at $p<0.05$.

In general, the results from the replanted field experiments were similar with the results from net-house-pot experiments. The densities of P. coffeae and M. incognita in the replanted coffee soil were 294 and 78 individuals/100 g soil, respectively, from the control (C.F), which was higher than in the soil from the M.F, G.F and MG.F treatments. Mycorrhizal symbiosis again indicated better effects on reducing nematode densities compared to the grafting due to the densities of the two nematodes in the soil from the M.F treatment being lower than that in the soil from the G.H treatment. However, there was no statistically significant difference of nematode densities between the control and grafting treatments. Similar to the net-house-pot results, the combination of mycorrhizal symbiosis and grafting helped strongly decrease the nematode densities in the soil to 98 individuals $/ 100 \mathrm{~g}$ soil for $P$. coffeae (Figure 2a) and 27 individuals/100 g soil for M. incognita (Figure 2b) $(p<0.05)$.

\subsection{Survival Rates and Growth Indicators of Young Robusta Trees in Replanted Field Experiments}

Similar to the results of the experiments carried out in net-house-pots, the treated young Robusta trees had higher survival rates than the control. These results of the two monitored years were in accordance with each other and are shown in Table 2. Generally, the ratio of tree deaths in the first year was higher than in the second year. Mycorrhizal symbiosis or/and grafting significantly improved the survival rates of young coffee trees during the two year cultivation in the replanted fields. Even though the mycorrhizal symbiosis seemed to enhance the survival rate more effectively than the grafting, the difference was not statistically significant. The combination of the two techniques considerably raised young Robusta viability from $60.5 \%$ for the C.F to $93.7 \%$ for the MG.F in the second year $(p<0.05)$. 
Table 2. Survival rate of the young Robusta coffee trees after 2 years of cultivation in the replanted fields.

\begin{tabular}{ccc}
\hline \multirow{2}{*}{ Treatment } & \multicolumn{2}{c}{ Survival Rate (\%) } \\
\cline { 2 - 3 } & First Year & Second Year \\
\hline C.F & $73.8^{\mathrm{a}}$ & $60.5^{\mathrm{a}}$ \\
M.F & $80.5^{\mathrm{b}}$ & $71.2^{\mathrm{b}}$ \\
G.F & $79.5^{\mathrm{b}}$ & $69.5^{\mathrm{b}}$ \\
MG.F & $95.8^{\mathrm{c}}$ & $93.7^{\mathrm{c}}$ \\
\hline CV (\%) & $4.37^{\circ}$ & 4.02 \\
LSD 0.05 & 3.152 & 2.781 \\
\hline
\end{tabular}

C.F, control; M.F, mycorrhizal symbiosis treatment; G.F, grafting treatment; MG.F, combined mycorrhizal symbiosis and grafting treatment. CV, Coefficient of variation. LSD, Least significant difference. Means with the same letters are not statistically different based on the least significant difference at $p<0.05$.

The growth indicators of young Robusta trees were monitored during two years of cultivation in a replanted coffee plantation and the brief results are shown in Table 3. For tree height, stump diameter and canopy diameter indicators, grafting seemed to create a better improvement compared to the mycorrhizal symbiosis. There was no difference in the number of first branch pairs between the M.F and the G.F $(p<0.05)$. The MG.F treatment had the highest growth indicators after two years of cultivation in the replanted fields.

Table 3. Growth indicators of the young Robusta coffee trees after 2 years of cultivation in the replanted fields.

\begin{tabular}{ccccc}
\hline Treatment & $\begin{array}{c}\text { Tree Height } \\
(\mathbf{c m})\end{array}$ & $\begin{array}{c}\text { Stump Diameter } \\
(\mathbf{c m})\end{array}$ & $\begin{array}{c}\text { Canopy Diameter } \\
(\mathbf{c m})\end{array}$ & $\begin{array}{c}\text { Number of 1st } \\
\text { Branch Pairs }\end{array}$ \\
\hline C.F & $112.6^{\mathrm{a}}$ & $2.41^{\mathrm{a}}$ & $126.7^{\mathrm{a}}$ & $10.5^{\mathrm{a}}$ \\
M.F & $116.8^{\mathrm{a}}$ & $2.58^{\mathrm{a}}$ & $129.4^{\mathrm{a}}$ & $10.4^{\mathrm{a}}$ \\
G.F & $128.6^{\mathrm{b}}$ & $3.72^{\mathrm{b}}$ & $142.7^{\mathrm{b}}$ & $10.4^{\mathrm{a}}$ \\
MG.F & $128.9^{\mathrm{b}}$ & $3.84^{\mathrm{b}}$ & $143.2^{\mathrm{b}}$ & $10.9^{\mathrm{b}}$ \\
\hline
\end{tabular}

C.F, control; M.F, mycorrhizal symbiosis treatment; G.F, grafting treatment; MG.F, combined mycorrhizal symbiosis and grafting treatment. Means with the same letters are not statistically different based on the least significant difference at $p<0.05$.

\section{Discussion}

The current study examined the effects of two cropping techniques including mycorrhizal symbiosis and grafting on nematode management to improve the replanting efficiency of young Robusta trees in replanted fields in the Daklak province, Vietnam. Three key findings arose from the study: Firstly, separately applying mycorrhizal symbiosis and grafting C. canephora scion onto C. liberica rootstock both slightly decreased nematode densities in the replanted coffee soil in the net-house-pots and plantations, consequently improving the viability and growth of young coffee trees. Secondly, even though the mycorrhizal symbiosis treatment indicated a better improvement on controlling nematodes in replanted coffee soil than the grafting treatment, the survival rate of the young Robusta trees treated by these two techniques were not statistically different $(p<0.05)$. Thirdly, the combination of the grafting and the mycorrhizal symbiosis that was recorded greatly decreased the nematode densities, leading to the highest efficiency on the seedling young Robusta coffee trees in the replanted fields.

In general, the treatments which resulted in high nematode densities in the soil would correspondingly lead to the low survival and growth rates of coffee plants. This result strengthens the assumption that nematodes are one of the reasons for low replanting efficiency. The most common coffee variety used as the rootstock for grafting is Robusta [23]. However, in order to improve the root development and the tree growth of Robusta, the most popular coffee variety in the Daklak province, Liberica is expected to be a good rootstock. The experimental results in net-house-pots as well as in the field of this study proved this expectation to be true. This result can be explained by Liberica's 
ability to endure extreme conditions and resist pests which has been reported to be better than that of Robusta [24]. On the other hand, mycorrhiza fungi have been used as an environmentally friendly agent to manage nematodes [25-27]. The two antagonistic fungi in the mycorrhiza commercial product, Trichoderma harzianum and Trichoderma viride, were reported to especially reduce $M$. incognita and P. coffeae $[28,29]$. The mycorrhizal symbiosis technique has also been applied to improve the growth and development of plants thanks to its ability to support nitrogen fixation as well as to absorb nutrients in the soil of the root system [30]. The study results once again confirmed this when both the M.H and M.F treatments had lower nematode densities in the soil, and enjoyed higher survival rates and growth indicators compared to the C.H and C.F, respectively.

It is interesting to be aware that even though the mycorrhizal symbiosis treatment indicated a better improvement on decreasing nematodes in replanted coffee soil than the grafting treatment, the survival rates of young Robusta trees separately treated by these two techniques (M.F and G.F) were not statistically different $(p<0.05)$. This can be explained by the main mechanisms of mycorrhiza fungi and grafting rootstock. Mycorrhiza fungi directly effects on the pathogen, by competiting for space or nutrients [31]. Hence, mycorrhiza fungi and nematodes most probably depend on common resources such as host photosynthate, nutrition, infection-site and space within the plant root for their survival and multiplication; hence competition can occur for these resources between nematodes and mycorrhizal fungi [32]. Meanwhile the main characteristics of the grafting technique are a better root development and pest tolerance, thus generating conditions so that the crop does not stop its metabolic activities such as the absorption of water and nutrients [18]. From these literatures, it can be assumed that the high survival rates of young Robusta trees in the M.H and M.F treatments were due to the nematode competition of mycorrhiza, while in the G.H and G.F treatments they were due to the nematode tolerance of the grafting rootstock.

The combination of the two techniques greatly decreased the nematode densities, leading to the highest benefit for the seedling young Robusta coffee trees in the replanted fields among the treatments. This combined technique took advantage of the benefits of each component technique. As a result, the efficiency of the nematode management in the replanted coffee fields was boosted by not only the decreasing nematode densities in the soil but also by the increasing nematode tolerance of trees. The combination of the mycorrhizal symbiosis and grafting techniques to manage nematodes has been studied and obtained positive results in several plants such as cucumber, plum and tomato [33-35]. The successful result of this combined technique in the nematode management would contribute as a useful reference to crop production in general and coffee production in particular. In the current research, the nematode densities in the soil as well as the survival rate and growth rate of young Robusta coffee trees were recorded for the first two years (the basic construction period). The effect of the combination of the mycorrhiza symbiotic and grafting techniques on the yield as well as on the quality of the coffee beans should also be further investigated.

\section{Materials and Methods}

\subsection{Field Sight}

The experiment was carried out in the Daklak province, located in the Central-Highlands in Vietnam. Its geographic coordinates are $12^{\circ} 40^{\prime} \mathrm{N}$ and $108^{\circ} 03^{\prime} \mathrm{E}$ with an average elevation of about 400 to $800 \mathrm{~m}$. Daklak province has a temperate climate, it is warm year-round and rarely changes yearly. Ferralsols (mainly red basaltic soil) is the main soil group in Daklak and occupies $23.7 \%$ area of the province [1].

\subsection{Materials}

The original plants of $C$. canephora and the grafting plants of $C$. canephora Scion onto the C. liberica Rootstock at 6-month age were supplied by the Daklak province plant nursery. Mycorrhizal symbiosis was performed by using a commercial mycorrhiza product, supplied by the Vietnam Soils and Fertilizers 
Research Institute, with three different species of mycorrhiza fungi including Glomus spp., Gigaspora spp., Acaulospora spp. and other nutrients and beneficial microorganisms (nitrogen fixing, phosphate solubilizing, and disease fungal antagonizing (T. harzianum and T. viride species)). The spore density of the used mycorrhiza product was $>100$ spores/g inoculants. A solution of mycorrhiza product was prepared at the concentration of $500 \mathrm{~g} /$ litter before inoculating. The nematode populations of $P$. coffeae and M. incognita were isolated from the research sites in the Daklak province following the centrifugal flotation method [36] and then cultured on carrot callus tissue [37]. Ten males and ten females of each population were used to prepare the nematode morphological collection slides following the De Grisse method [38]. The nematode samples were fixed, observed under electronic microscopes and identified by the classification method of Castillo and Volvlas [11,39].

\subsection{Evaluation of the Effect of Mycorrhizal Symbiosis and Grafting Techniques on Nematode Densities in Net-House-Pots}

The experiment was carried out from November 2015 to June 2018 in a randomized complete block design in the net-house of the Vietnam Soils and Fertilizers Research Institute as follows: treatments = 4; treatment size $=15$; replication $=3$ (Table 4 ). The ambient condition of the net-house was similar to the local climate, whose temperature was $22-27^{\circ} \mathrm{C}$ and humidity was $70-90 \%$. The soil was collected from the replanted coffee plantations in the $\mathrm{Cu} \mathrm{M}^{\prime}$ gar district, Daklak province, and transported to the experimental net-house and then sterilized to kill all pathogens in the soil before filling into polythene bags and pots in the net-house for the experiments. The soil amounts in each polythene bag and pot were $2 \mathrm{~kg}$ and $5 \mathrm{~kg}$, respectively. Nematode and mycorrhiza inoculations were separately performed as follows: the mycorrhiza were added by directly irrigating mycorrhiza product solution into soil. The first mycorrhizal inoculation into the nursery was carried out at a dose of $100 \mathrm{~g} / \mathrm{plant}$ and then the inoculated plants (in polythene bags) were left for 5 days before being transferred to pots. After 3 months, the second mycorrhizal inoculation into the pots was performed with the amount of $100 \mathrm{~g} /$ tree. After transferring the coffee plants from the polythene bags to pots, 5000 nematode individuals were added into every pot. Ten days later, the second nematode inoculation into the pots was conducted with the same dose. The individual ratio of $P$. coffeae and $M$. incognita in each 5000-individual population was chosen as 2:1 due to fact that the initial densities of $P$. coffeae and $M$. incognita were found to be $112 \pm 11$ and $31 \pm 7$ individuals/100g soil, respectively (individual ratio was approximately 2). This meant that there were 10,000 nematode individuals and $200 \mathrm{~g}$ mycorrhizal products (approximately 20,000 mycorrhiza spores) inoculated in each pot (tree). In other words, there were approximate $134 \mathrm{P}$. coffeae individuals, $66 \mathrm{M}$. incognita individuals and 400 mycorrhiza spores in $100 \mathrm{~g}$ of pot soil. The amount of nitrogen-phosphorus-potassium (NPK) fertilizer was calculated and applied according to the following local procedure: 12 tons of manure; $60 \mathrm{~N} ; 90 \mathrm{P}_{2} \mathrm{O}_{5} ; 40 \mathrm{~K}_{2} \mathrm{O} / \mathrm{ha}$ (first year); $90 \mathrm{~N} ; 90 \mathrm{P}_{2} \mathrm{O}_{5} ; 90 \mathrm{~K}_{2} \mathrm{O} /$ ha (second year). The survival rate and growth indicators such as tree height, stump diameter, canopy diameter and number of first level branch pairs were monitored every 6 months over 2 years. The densities of nematodes in the soil were determined after 2 years of cultivation.

Table 4. Treatments for evaluating the effect of the mycorrhizal symbiosis and grafting techniques on the nematode densities in the net-house-pots.

\begin{tabular}{cr}
\hline Treatment & Description \\
\hline C.H & Control (neither mycorrhizal symbiosis nor grafting) in net-house-pot \\
M.H & Mycorrhizal symbiosis treatment in net-house-pot \\
G.H & Grafting treatment in net-house-pot \\
MG.H & Combined mycorrhizal symbiosis and grafting in net-house-pot \\
\hline
\end{tabular}

C.H, control; M.H, mycorrhizal symbiosis treatment; G.H, grafting treatment; MG.H, combined mycorrhizal symbiosis and grafting treatment. 


\subsection{Evaluation of the Effect of Mycorrhizal Symbiosis and Grafting Techniques on Nematode Densities in Replanted Coffee Fields}

The experiment was carried out from November 2016 to June 2019 in a randomized complete block design in a replanted coffee plantation in the $\mathrm{Cu}^{\mathrm{M}}$ 'gar district, Daklak province, as follows: treatments $=4$; replication $=4$; block area $=250 \mathrm{~m}^{2}$; planting hole size $=3 \mathrm{~m} \times 3 \mathrm{~m}$ (Table 5). The soil in the plantation was red brown soil developed on basalt. After uprooting the old coffee trees, the soil was applied lime and dried for 6 months during the dry season. In the process of tillage, the remaining coffee roots were picked up. The mycorrhiza product was applied twice. The first inoculation into the nursery was carried out at a dose of $100 \mathrm{~g} /$ plant. After 4 months of growing the coffee trees in the replanted soil, the second inoculation was performed with the amount of $100 \mathrm{~g} /$ tree. The amount of NPK fertilizer was applied similarly to the net-house experiments. The survival rate and growth indicators as well as the nematode densities were monitored similarly to the net-house experiments.

Table 5. Treatments for evaluating the effect of the mycorrhizal symbiosis and grafting techniques on the nematode densities in the replanted fields.

\begin{tabular}{cr}
\hline Treatment & Description \\
\hline C.F & Control (neither mycorrhizal symbiosis nor grafting) in replanted fields \\
M.F & Mycorrhizal symbiosis treatment in replanted fields \\
G.F & Grafting treatment in replanted fields \\
MG.F & Combined mycorrhizal symbiosis and grafting in replanted fields \\
\hline
\end{tabular}

C.F, control; M.F, mycorrhizal symbiosis treatment; G.F, grafting treatment; MG.F, combined mycorrhizal symbiosis and grafting treatment.

\subsection{Data Collection and Analysis}

The survival rate of the coffee plants was determined by the following formulation:

$$
\text { Survival rate }(\%)=\frac{\mathrm{B}-\mathrm{A}}{\mathrm{A}} \times 100 \%
$$

where: A was the total of dead plants and plants with yellowing leaves and B was the total experimental plants.

The data was aggregated and analyzed using the Statistic Analyze Software of Excel.

\section{Conclusions}

The separate treatments, namely the mycorrhizal symbiosis and the grafting of $C$. canephora scion onto the C. liberica rootstock, slightly decreased the nematode densities in the replanted coffee soil in the net-house-pots and in the replanted fields, and consequently improved the viability and growth of the young coffee trees. The mycorrhizal symbiosis treatment indicated a better improvement on controlling the nematode density in replanted coffee soil than the grafting treatment but the survival rates of the young Robusta trees treated by these two techniques were similar. The combination of grafting and the mycorrhizal symbiosis was recorded to greatly decrease the nematode densities, leading to the highest efficiency on the seedling young Robusta coffee trees in the replanted fields. The efficiency of nematode management in the replanted coffee fields was boosted not only by the decreasing nematode densities in the soil but also by the increasing nematode tolerance of the trees. This recommends that the combined technique of grafting and mycorrhizal symbiosis would be an appropriate cropping practice to manage nematodes in replanted coffee fields in the Daklak province, Vietnam. In the future, how this combination effects on yield and the quality of coffee beans should also be further investigated. 
Author Contributions: Conceptualization, N.T.T.L. and T.T.P.; methodology, T.T.P.; software, B.L.G.; validation, N.H.N., V.D.M.H. and B.T.L.H.; formal analysis, V.D.M.H.; investigation, N.T.T.L.; resources, T.T.P.; data curation, P.N.D.Y.; writing-original draft preparation, N.H.N.; writing-review and editing, N.T.T.L.; visualization, B.T.L.H.; supervision, N.T.T.L.; project administration, B.L.G.; funding acquisition, P.N.D.Y. All authors have read and agreed to the published version of the manuscript.

Funding: This research received no external funding.

Conflicts of Interest: The authors declare no conflict of interest.

\section{References}

1. Thuy, P.T.; Niem, L.D.; Ho, T.M.H.; Burny, P.; Lebailly, P. Economic Analysis of Perennial Crop Systems in DakLak Province, Vietnam. Sustainability 2019, 11, 81. [CrossRef]

2. Ho, T.Q. Economic Analysis of Sustainable Coffee Production in Vietnam; Queensland University of Technology: Brisbane, Australia, 2018.

3. Lindskog, E.; Dow, K.; Axberg, G.N.; Miller, F.; Hancock, A. When Rapid Changes in Environmental, Social and Economic Conditions Converge: Challenges to Sustainable Livelihoods in Dak Lak, Vietnam; Stockholm Environment Institute (SEI): Stockholm, Sweden, 2005.

4. Nguyen, T.V.; Nguyen, N.C.; Bosch, O.J. Contribution of the systems thinking approach to reduce production cost and improve the quality of Vietnamese coffee. Int. J. Mark. Bus. Syst. 2015, 1, 53-69. [CrossRef]

5. Steps Toward Green: Policy Responses to the Environmental Footprint of Commodity Agriculture in East and Southeast Asia. Available online: https://www.researchgate.net/publication/282768221_Steps_Toward_ Green_Policy_Responses_to_the_Environmental_Footprint_of_Commodity_Agriculture_in_East_and_ Southeast_Asia (accessed on 31 January 2015).

6. Zhao, Q.; Xiong, W.; Xing, Y.; Sun, Y.; Lin, X.; Dong, Y. Long-Term Coffee Monoculture Alters Soil Chemical Properties and Microbial Communities. Sci. Rep. 2018, 8, 11. [CrossRef] [PubMed]

7. Ntalli, N.G.; Caboni, P. Botanical nematicides: A review. J. Agric. Food Chem. 2012, 60, 9929-9940. [CrossRef]

8. Ntalli, N.G.; Menkissoglu-Spiroudi, U. Pesticides of Botanical Origin: A Promising Tool Plant Protection, Pesticides-Formulations, Effects, Fate; Stoytcheva, M., Ed.; IntechOpen: London, UK, 2011; pp. 1-23.

9. Le, V.T.; Bach, L.G.; Pham, T.T.; Le, N.T.T.; Ngoc, U.T.P.; Tran, D.-H.N.; Nguyen, D.H. Synthesis and antifungal activity of chitosan-silver nanocomposite synergize fungicide against Phytophthora capsici. J. Macromol. Sci. Part A 2019, 56, 522-528. [CrossRef]

10. Ngoc, U.T.P.; Nguyen, D.H. Synergistic antifungal effect of fungicide and chitosan-silver nanoparticles on Neoscytalidium dimidiatum. Green Process. Synth. 2018, 7, 132-138. [CrossRef]

11. Trinh, P.Q.; de la Peña, E.; Nguyen, C.N.; Nguyen, H.X.; Moens, M. Plant-parasitic nematodes associated with coffee in Vietnam. Russ. J. Nematol. 2009, 17, 73.

12. Huyen, P.T.T.; Giang, P.Q.; Van Toan, N. Correlation between the Distribution of Nematodes and Soil Physicochemical Characteristics in Coffee Rejuvenation Areas. EnvironmentAsia 2018, 11, 141-156.

13. Latef, A.A.H.A.; Hashem, A.; Rasool, S.; Abd_Allah, E.F.; Alqarawi, A.; Egamberdieva, D.; Jan, S.; Anjum, N.A.; Ahmad, P. Arbuscular mycorrhizal symbiosis and abiotic stress in plants: A review. J. Plant Biol. 2016, 59, 407-426. [CrossRef]

14. Parniske, M. Arbuscular mycorrhiza: The mother of plant root endosymbioses. Nat. Rev. Microbiol. 2008, 6, 763-775. [CrossRef]

15. Andrade, S.; Mazzafera, P.; Schiavinato, M.; Silveira, A. Arbuscular mycorrhizal association in coffee. J. Agric. Sci. 2009, 147, 105-115. [CrossRef]

16. Posada, R.; Sieverding, E. Arbuscular mycorrhiza in Colombian coffee plantations fertilized with coffee pulps as organic manure. J. Appl. Bot. Food Qual. 2014, 87, 243-248.

17. Beenhouwer, M.D.; Geel, M.V.; Ceulemans, T.; Muleta, D.; Lievens, B.; Honnay, O. Changing soil characteristics alter the arbuscular mycorrhizal fungi communities of Arabica coffee (Coffea arabica) in Ethiopia across a management intensity gradient. Soil Biol. Biochem. 2015, 91, 7. [CrossRef] 
18. Sánchez-Rodríguez, E.; Romero, L.; Ruiz, J.M. Role of Grafting in Resistance to Water Stress in Tomato Plants: Ammonia Production and Assimilation. J. Plant Growth Regul. 2013, 32, 12. [CrossRef]

19. Novaes, P.; Souza, J.P.; Prado, C.H.B.A. Grafting for improving net photosynthesis of coffea arabica in field in Southeast of Brazil. Exp. Agric. 2011, 47, 16. [CrossRef]

20. Daivasikamani, S.; Kannan, S.; Ramachandran, M.; Samuel, S. Abnormal growth of shoots on scions of arabica coffee grafted on to robusta root stock. J. Coffee Res. 2004, 32, 117-119.

21. Wiryadiputra, S.; Tran, L.K. Indonesia and Vietnam; Springer: New York, NY, USA, 2008.

22. Chapman, K.R. Collaborative Study of Coffee Rejuvenation Strategies in Viet Nam -Technical Aspects-; FAO: Bangkok, Thailand, 2014.

23. Júnior, S.d.A.; Alexandre, R.S.; Schmildt, E.R.; Partelli, F.L.; Ferrão, M.A.G.; Mauri, A.L. Comparison between grafting and cutting as vegetative propagation methods for conilon coffee plants. Agron. Mar. 2013, 35, 9. [CrossRef]

24. Anzueto, F.; Baumann, T.W.; Graziosi, G.; Piccin, C.R.; Ndahl, M.R.S.; Vossen, H.A.M.v.d. Espresso Coffee-Chapter 2: The Plant; Elsevier: Amsterdam, The Netherlands, 2015. [CrossRef]

25. Schouteden, N.; De Waele, D.; Panis, B.; Vos, C.M. Arbuscular Mycorrhizal Fungi for the Biocontrol of Plant-Parasitic Nematodes: A Review of the Mechanisms Involved. Front. Microbiol. 2015, 6. [CrossRef]

26. Pinochet, J.; Calvet, C.; Camprubi, A.; Fernandez, C. Interactions between migratory endoparasitic nematodes and arbuscular mycorrhizal fungi in perennial crops: A review. Plant Soil 1996, 185, 183-190. [CrossRef]

27. Akhtar, M.; Panwar, J. Arbuscular mycorrhizal fungi and opportunistic fungi: Efficient root symbionts for the management of plant parasitic nematodes. Adv. Sci. Eng. Med. 2011, 3, 165-175. [CrossRef]

28. El-Nagdi, W.M.; Youssef, M.M.; El-Khair, H.A.; Abd-Elgawad, M.M. Effect of certain organic amendments and Trichoderma species on the root-knot nematode, Meloidogyne incognita, infecting pea (Pisum sativum L.) plants. Egypt. J. Biol. Pest Control 2019, 29, 75. [CrossRef]

29. Masadeh, B.; Von Alten, H.; Grunewaldt-Stoecker, G.; Sikora, R. Biocontrol of root-knot nematodes using the arbuscular mycorrhizal fungus Glomus intraradices and the antagonist Trichoderma viride in two tomato cultivars differing in their suitability as hosts for the nematodes/Biologische Bekämpfung von Gallennematoden unter Verwendung des arbusculären Mykorrhizapilzes Glomus intraradices und des Antagonisten Trichoderma viride in zwei Tomatensorten mit unterschiedlicher Wirtseignung für Gallennematoden. Zeitschrift für Pflanzenkrankheiten und Pflanzenschutz/J. Plant Dis. Prot. 2004, 111, 322-333.

30. Bitterlich, M.; Rouphael, Y.; Graefe, J.; Franken, P. Arbuscular Mycorrhizas: A Promising Component of Plant Production Systems Provided Favorable Conditions for Their Growth. Front. Plant Sci. 2018, 9, 6. [CrossRef] [PubMed]

31. Cameron, D.D.; Neal, A.L.; Wees, S.C.M.v.; Ton, J. Mycorrhiza-induced resistance: More than the sum of its parts? Trends Plant Sci. 2013, 18, 6. [CrossRef]

32. Ishwar, S.; Bhoopander, G. Arbuscular Mycorrhiza Mediated Control of Plant Pathogens; Springer: Cham, Switzerland, 2017. [CrossRef]

33. Babaj, I.; Sallaku, G.; Balliu, A. The effects of endogenous mycorrhiza (Glomus spp.) on plant growth and yield of grafted cucumber (Cucumis sativum l) under common commercial greenhouse conditions. Albanian J. Agric. Sci. 2014, 13, 24.

34. Batlle, A.; Lavina, A.; Sabate, J.; Camprubi, A.; Estaun, V.; Calvet, C. Tolerance increase to Candidatus phytoplasma prunorum in mycorrhizal plums fruit trees. Bull. Insectol. 2011, 64, 125-126.

35. Garita, S.A.; Bernardo, V.F.; Guimarães, M.D.A.; Arango, M.C.; Ruscitti, M.F. Mycorrhization and grafting improve growth in the tomato and reduce the population of Nacobbus aberrans. Rev. Ciência Agronômica 2019, 50, 609-615. [CrossRef]

36. Van Bezooijen, J. Methods and Techniques for Nematology; Wageningen University Wageningen: Wageningen, The Netherlands, 2006.

37. Elele, K. The use of selected plant tissues [Carrot (Daucus carota, Linnaeus, 1753), Pineapple (Anana comosus, Merill, 1917) and yam (Dioscorea spp. Linnaeus, 1753)] for in vitro nematode propagation (Meloidogyne spp. Goeldi, 1892 and Rotylenchulus reniformis, Lindford and Oliveira, 1940). Adv. Agric. Sci. Eng. Res. 2012, 2, 388-400. 
38. De Grisse, A.T. Redescription ou Modifications de Quelques Technique Utilis [a] es Dan L'etude des $n$ [a] Ematodes Phytoparasitaires; Mededelingen Rijksfakulteit Landbouwwetenschappen: Ghent, Belgium, 1969.

39. Castillo, P.; Vovlas, N. Pratylenchus (Nematoda: Pratylenchidae): Diagnosis, Biology, Pathogenicity and Management; Brill: Leiden, The Netherlands, 2007; Volume 6.

(cc) (1)

(C) 2020 by the authors. Licensee MDPI, Basel, Switzerland. This article is an open access article distributed under the terms and conditions of the Creative Commons Attribution (CC BY) license (http://creativecommons.org/licenses/by/4.0/). 